\title{
The consequences of increasing block tariffs on the distribution of residential electricity subsidies in Addis Ababa, Ethiopia
}

DOI:

10.1016/j.enpol.2019.01.033

\section{Document Version}

Accepted author manuscript

Link to publication record in Manchester Research Explorer

Citation for published version (APA):

Cardenas, H., \& Whittington, D. (2019). The consequences of increasing block tariffs on the distribution of residential electricity subsidies in Addis Ababa, Ethiopia. Energy Policy, 128, 783-795.

https://doi.org/10.1016/j.enpol.2019.01.033

\section{Published in:}

Energy Policy

\section{Citing this paper}

Please note that where the full-text provided on Manchester Research Explorer is the Author Accepted Manuscript or Proof version this may differ from the final Published version. If citing, it is advised that you check and use the publisher's definitive version.

\section{General rights}

Copyright and moral rights for the publications made accessible in the Research Explorer are retained by the authors and/or other copyright owners and it is a condition of accessing publications that users recognise and abide by the legal requirements associated with these rights.

\section{Takedown policy}

If you believe that this document breaches copyright please refer to the University of Manchester's Takedown Procedures [http://man.ac.uk/04Y6Bo] or contact uml.scholarlycommunications@manchester.ac.uk providing relevant details, so we can investigate your claim.

\section{OPEN ACCESS}


The Consequences of Increasing Block Tariffs on the Distribution of Residential Electricity Subsidies in Addis Ababa, Ethiopia

\author{
By \\ Helena Cardenas ${ }^{1}$ \\ and \\ Dale Whittington ${ }^{2}$
}

June 9, 2018

1 Corresponding author. Department of City and Regional Planning, University of North Carolina at Chapel Hill. New East Building, CB \#3140, NC 27599. Email: helenacd@live.unc.edu.

2 Department of City and Regional Planning and Gillings School of Global Public Health, University of North Carolina at Chapel Hill, and Global Development Institute, University of Manchester. 204 New East Building, CB \#3140, NC 27599. Email: dale_whittington@unc.edu. 


\begin{abstract}
This study evaluates the distribution of electricity subsidies to residential customers in Addis Ababa, Ethiopia in 2016 that results from the current increasing block tariff (IBT) structure. Customer billing data supplied by the electricity utility was matched with socioeconomic information collected from a survey of 987 households, and used with a utility-specific estimate of the costs of electricity service to estimate household-specific subsidies. The analysis differentiates between primary customers, who own an electricity account, and nonprimary customers, who pay a primary account holder, and presents the first detailed analysis of the incidence of subsidies provided to households with private versus shared electricity connections. Results show that households in the poorest quintile received $7 \%$ of the total subsidy, while households in the wealthiest quintile received $37 \%$. The majority of households with shared connections were in poorer quintiles, and $80 \%$ in the poorest quintile were nonprimary customers. The regressive outcomes of the IBT structure are explained by two of its attributes: (1) the volumetric rates in all tariff blocks are substantially below the total average cost of delivery of the service; and (2) there is only a moderate association between electricity consumption and household wealth.
\end{abstract}

Keywords: electricity residential consumption; increasing block tariff; subsidy leakage; subsidy incidence; Addis Ababa, Ethiopia. 


\section{Introduction}

Government subsidies for publicly provided electricity services are politically popular and widespread in low- and middle-income countries, in large part because they provide the majority of the population with a direct financial benefit. Heavily subsidized electricity services cause four interrelated problems. First, providers have little incentive to produce services efficiently, i.e., production inefficiency (Ahmed et al. 2012; Komives et al. 2009). Second, consumers have little incentive to use services wisely, i.e., allocative inefficiency (Komives et al. 2009; Mayer et al. 2015). Third, subsidized services place stress on government budgets and displace other, higher-priority government spending objectives (Mayer et al. 2015; Komives et al. 2009; Wodon et al. 2003; Ahmed et al. 2012). Fourth, subsidies for electricity benefit primarily middle- and upper-income households, thus increasing income inequality (Trimble et al. 2011; Komives et al. 2009; Mayer et al. 2015; Wodon et al. 2003; Angel-Urdiola and Wodon 2005; Ahmed et al. 2012).

We focus here on the fourth problem, the tendency for subsidized services to benefit betteroff customers more than those who need subsidies the most (poor households). Using estimates we calculated of the magnitude of electricity subsidies that households in Addis Ababa, Ethiopia, received in 2015/2016, we examined the distribution of these subsidies by wealth categories. In this paper we define 'subsidy' as the difference between the total cost of providing a customer with electricity service and the payment a customer makes to the utility for the service. In our analysis, the customers' payments are always less than the costs of providing them with service, which means that all households receive a subsidy. ${ }^{1}$

\footnotetext{
1 This subsidy is paid by higher-level government and donors that have financed the costs of the electricity infrastructure and pay for part of the costs of operation and maintenance. To the best of
} 
Our approach for these calculations relied on data from three sources: (1) our estimates of the total average costs of electricity services in Addis Ababa, based primarily on the financial data obtained from the electricity utility company; (2) customer billing records for a random sample of the utility's residential customers; and (3) in-person interviews with respondents from a random sample of 987 households with access to electricity services. These data allowed us to match household electricity billing records with household demographic and socioeconomic data collected in the household survey.

The electricity utility in Addis Ababa uses an increasing block tariff (IBT) to calculate its customers' monthly bills. The two main rationales for the use of IBTs in the electricity sector are (1) that the bills paid by high-income households will cross-subsidize the bills paid by low-income households, and (2) that the prices in the higher blocks of the IBT will be a price signal to promote more efficient electricity use. Yet previous research has shown that quantity-based electricity subsidies delivered through a tariff structure are regressive (Komives et al. 2009). One objective of our analysis is to determine whether the IBT used in Addis Ababa to calculate households' electricity bills effectively targets electricity subsidies to poor households.

Our analysis makes four contributions to the subsidy incidence literature. First, previous studies have not addressed the reality that in many cases two or more households may share a single electricity connection. We provide the first detailed analysis of the incidence of subsidies provided to households with shared electricity connections, differentiating

our knowledge, the Government of Ethiopia has not offered an explicit rationale to the public for this subsidy, but such subsidies are commonly intended to promote economic development and improve the lives of poor households. 
between primary customers (households that receive the bill and pay the utility company) and nonprimary customers (households that share in a connection and pay a portion of the bill to the primary customer).

Second, very few previous studies have matched actual customer billing records with household socioeconomic data. From the studies covered in our literature review only Lampietti et al. (2003) follows this procedure (refer to Table 1). While the other studies rely on self-reported electricity expenditures, back-calculating electricity use from the prevailing tariff structure (see Fuente et al., 2016, on problems arising with back-calculation methods in a study of municipal water supply).

Third, most previous studies do not base their subsidy calculations on the electricity utility's actual cost of service in the study location (Mayer et al. 2015; Lampietti et al. 2003; Angel Urdionla and Wodon 2003; Ahmed et al. 2012). Instead these studies assume local costs to be the same as a national or international cost estimate.

Fourth, little previous research has appeared on the distribution of electricity subsidies in cities in Sub-Saharan Africa. Only the cases of Cape Verde, Sao Tome and Principe, and Rwanda have been evaluated in a study by Angel-Urdiola and Wodon (2005).

The next, second section of the paper reviews existing literature on the incidence of subsidies in the electricity utility sector in low- and middle-income countries. The third section describes the IBT structure employed in Addis Ababa as of 2016. The fourth section discusses our data collection activities, sampling strategy, and fieldwork. The fifth section presents the methodology used to calculate the subsidies received by sample households 
and how we estimated the total average cost of electricity service. The sixth section presents the results of our analysis, and the seventh offers some concluding observations.

\section{Literature on the incidence of electricity subsidies in low- and middle-income countries}

We have restricted this review to articles about electricity services provided by publicly owned utilities in developing countries that were published in refereed journals or as World Bank working papers.

\subsection{Types of subsidies}

Subsidy incidence analysis of public services has been a topic of analysis since the 1990s. We focus here on two main types of subsidy programs. First, a program may target beneficiary households by identifying specific qualifying household characteristics such as past military service, retirement, low income, or location in an impoverished locality. This approach requires that the government or utility develop a procedure for identifying target households. Second, a program may deliver subsidies through the tariff structure itself, by selling some services below total average cost. This approach, termed a "quantity-based mechanism," is based on assumptions about the quantity of services that a poor household needs or uses, as compared to a wealthier household. In this case the tariff structure is designed to attempt to target subsidies to poor households effectively.

\subsection{Evaluating subsidies}


In general, subsidy programs have been evaluated according to three different metrics: beneficiary incidence, benefit incidence, and materiality or magnitude of the subsidy.

Beneficiary incidence analyses address the question, "Of the total number of poor households, what proportion receive the subsidy?" The answer to this question provides a measure of poor households' access to public services. This metric is most relevant when a substantial proportion of a target population (e.g., poor households) does not have access to these services. Results are typically presented as the share of targeted households that received the subsidy, or as the share of poor households excluded from receiving the subsidy ("errors of exclusion").

Benefit incidence analyses ask the question, "How well does the subsidy benefit poor households, as compared to other households?" The answer describes the distribution of the total subsidy across different income or wealth groups in the total population. All of the studies in this review that report findings for benefit incidence divide the population into income categories (either quintiles or deciles). A few also report the distribution of subsidies to groups above and below a poverty line (Wodon et al 2003; Mayer et al. 2015). Some authors use a government poverty line to distinguish between poor and nonpoor households (Mayer et al 2015; Ahmed et al. 2012; Angel-Urdiola and Wodon 2005; Wodon et al 2003); others use data on income and/or wealth (Ahmed et al. 2012; Trimble et al. 2011; Komives et al. 2009; Lampietti et al 2003; Mayer et al. 2015). Most benefit incidence studies use data from secondary household surveys to obtain information on income and wealth, but do not provide a detailed description of the data used, e.g., whether annual income, annual expenditures, household assets (Ahmed et al. 2012; Lampietti et al. 2003; Trimble et al. 2011; Komives et al. 2009). In a benefit incidence analysis the distribution or 
incidence of subsidies would be defined as "regressive" if rich households received a high proportion of the total subsidies delivered to all households.

Magnitude or materiality of the subsidy ask the question, "How substantial is the amount of subsidy received by poor households, or by the population as a whole?" The answer is generally reported as the total amount of the subsidy as a proportion of the total financial cost of service provision, or as a proportion of a national macroeconomic measure such as GDP or the fiscal deficit. For example, Mayer, Banerjee, and Trimble (2015) calculated that residential electricity customers in India only paid about $13 \%$ of the financial cost of these services, and that subsidies to residential electricity customers represented about $0.4 \%$ of the national GDP. Trimble, Yoshida, and Saqil (2011) calculated that residential electricity customers in Pakistan paid only about $10 \%$ of the financial costs of providing these services. Komives, Johnson, and Halpern (2009) found that the cost of electricity subsidies in Mexico was about US $\$ 9$ billion, which represented about $0.7 \%$ of the national GDP. ${ }^{2}$ Wodon, Ajwad, and Siaens (2003) estimated that annual electricity subsidies for residential customers in Honduras cost the government US $\$ 17.5$ million, about $0.34 \%$ of the national GDP. Ahmed, Trimble, and Yoshida (2012) found that the share of the budget spent on electricity subsidies for the residential customers in Bangladesh increased from $0.2 \%$ of the national GDP in 2010 to $0.8 \%$ in 2012.

These studies show that the magnitude of electricity subsidies for residential customers in some developing countries represents a large burden on the public budget. These subsidies are high because utility services are priced far below the total average cost. Many

\footnotetext{
2 The electricity subsidies are expressed in US dollars of the year that each subsidy was analyzed in the study pertaining to it. For the cases of Honduras and Bangladesh, we calculated the percentage of the budget spent on subsidies from the national GDP, by using the expenditures reported in the cited studies and the World Bank development indicators of the year of the analysis.
} 
developing countries subsidize electricity for very large proportions of their residential customers (Mayer et al. 2015; Trimble et al. 2011).

\subsection{The increasing block tariff (IBT) structure}

Most of the papers covered in this review report on a quantity-based mechanism for delivering subsidies (i.e., the subsidies are delivered through the tariff structure). In the electricity sector, the most common quantity-based mechanism is the IBT. As we summarize in Table 1, from the covered case studies that use a quantity-based mechanism, only one uses a different tariff structure; this is the case of Rwanda, which uses a uniform volumetric tariff (Angel-Urdiola and Wodon 2005). Studies reviewed here from locations where IBTs were in force include India (Mayer, Banerjee, and Trimble 2015), Pakistan (Trimble, Yoshida, and Saqib 2011), Mexico (Komives et al. 2009), Honduras (Wodon et al. 2003), Cape Verde and Sao Tome (Angel-Urdiola and Wodon 2005), and Bangladesh (Ahmed, Trimble, and Yoshida 2012).

Benefit incidence studies find that IBTs do not result in high-income households crosssubsidizing low-income households, but rather that the use of IBTs is generally associated with high rates of errors of exclusion and inclusion and with high shares of subsidies being allocated to the highest-income groups. Table 1 indicates that in every case where the effects of an IBT have been studied, the beneficiary incidence analysis has shown a regressive result.

\subsection{Simulations of revised tariffs}

Several authors not only analyzed results of the status quo subsidy program in their study locations but also simulated how different modifications to the subsidy programs would 
change the distribution or targeting of subsidies. Ahmed, Trimble, and Yoshida (2012)

analyze the distributional consequences of a policy change toward cost-recovery pricing and universal household access to electricity services. Angel-Urdiola and Wodon (2005) simulated the targeting performance of different tariff structures and found that a shift from IBTs to volume-differentiated tariff structures (VDTs) would improve targeting performance. ${ }^{3}$ They also report an improvement in targeting if subsidies are provided for electricity connections as opposed to electricity consumption.

Several authors simulated the consequences of different tariff structures for electricity in more than one case or country. Komives et al. (2006) evaluated quantity-based subsidies versus means-tested subsidies and concluded that quantity-based subsidies delivered through the tariff structure are highly regressive. They found that in most cases geographically targeted and means-tested subsidies were progressive, but had significant errors of exclusion.

\subsection{Data considerations}

All papers included in this literature review illustrate three main data challenges: estimation of the cost of service provision, measurement of the quantity of the service a household uses, and estimation of individual household income and expenditures on electricity service.

\footnotetext{
${ }^{3}$ A volume-differentiated tariff (VDT), sometimes called a "ratchet" IBT, is used to calculate a household's service bill when households use more than the lifeline (lowest-priced) block. In this case the household is charged the price per kilowatt-hour in the highest block in which their electricity use falls for their entire electricity use.
} 
Estimating the cost of service provision. As shown in Table 1, most studies use estimates for the average unit cost of electricity based on data from national or local institutions. Trimble et al. (2011) used reference data on resources used for electricity provision and capital and operational costs. Mayer et al. (2015) calculated an estimate of the average unit cost by using an aggregate state-level measure of energy expenditure and the net input of energy. Komives et al. (2009) collected primary data from the utility companies' reported capital and operational costs. In contrast, Lampietti et al. (2003) used a reference cost from the United States State Department. Angel-Urdiola and Wodon (2005) and Ahmed et al. (2012) used a reference cost estimate, but in neither case is the source of the estimate reported. Although in some cases national or global data on the costs of electricity services may be the only way to approximate costs of electricity production and distribution, where possible, estimates of the total average unit cost of service delivery should be based on cost data obtained from the municipal service provider.

Estimating household income. Most studies in our literature review rely on secondary data for their measure of income. They generally use national surveys on Household Income and Expenditures (Ahmed et al. 2012; Trimble et al. 2011; Komives et at 2009; Lampietti et al 2003; Mayer et al. 2015). However, these studies do not provide detailed information on the data on income that they use, and whether they evaluate other data on wealth (e.g. households' assets, housing characteristics, households' expenditures) for comparison and due to possible miss reporting of income.

Measuring the quantity of the service a household uses. As shown in Table 1, for estimating household electricity usage most authors have relied on self-reported data from household expenditure surveys to estimate household electricity use rather than data from the utility's 
customer billing records, which are based on metered consumption (Mayer et al. 2015; Trimble et al. 2012; Komives et al. 2009; Wodon et al. 2003; Angel-Urdiola and Wodon 2005; Ahmed et al. 2012). There are two main problems with this approach. First, the respondent in a household survey may not know the amount of the past month's electricity bill and may simply guess. Second, researchers typically use the self-reported monthly bill to back-calculate an estimate of the quantity of service used and the average price paid based on the existing tariff structure. This assumes that the utility actually applies the official tariff when it calculates customers' monthly bills.

Estimating expenditures for shared connections. Further problems arise with accounting for shared connections. Household consumption and expenditure surveys usually do not clearly make a distinction between the amount paid by the group of households sharing a connection and the share of the total bill paid by each respondent's household. Moreover, when an owner and tenants in a building or compound share a connection, the owner may report only the total bill without indicating whether the tenants reimburse their respective portions of any or all of it. Other studies restrict their analysis to households with private connections for the exclusive use of household members and exclude shared connections altogether (Barde and Lehman 2014). Still other studies use customer-billing records with data on metered usage but nevertheless are unable to distinguish between households with a connection for the exclusive use of members and households sharing their connection with other households (Lampietti et al. 2003). Without information on how many households share a connection, the analyst cannot use the primary customer's electricity bill to back-calculate the quantity of electricity a household uses or the subsidy it receives. 
Summary. Our study addresses four of the data challenges revealed in this literature review. First, we employed data collected from the electricity utility's customer billing records, rather than relying on households' self-reported monthly expenditures to back-calculate quantities consumed and prices paid. Second, we implemented a primary data collection effort (a household survey) to estimate households' income and assets and to create a wealth index variable. In this household survey, we interview both, primary customers and households sharing an electricity connection. The primary customers interviewed in the survey were then matched with their electricity utility billing records. Third, our sampling strategy enabled us to differentiate in our subsidy analysis between households with private connections for their own exclusive use and households using a shared electricity connection. Fourth, we collected financial data from the electricity utility in Addis Ababa in order to estimate the total average cost of service in the city rather than relying on cost estimates from other locations.

A fourth contribution of this paper is that it adds to the small number of subsidy incidence studies in Africa. As shown in Table 1, the literature includes only three African case studies (Cape Verde, Sao Tome, and Rwanda).

[Table 1 about here]

\section{Background: electricity coverage and the electricity tariff in Addis Ababa}

In the decade leading up to spring 2016, when our study was completed, Addis Ababa had experienced rapid population and economic growth. The population had increased from 2.7 million in 2007 to 3.5 million in 2014 (CSA 2014). Between 2011 and 2015 household 
income increased 9\% annually in real terms (World Bank Living Standard Studies, 2011, 2015). But despite this strong national growth, $20 \%$ of households in Addis Ababa remained in extreme poverty, and an additional $29 \%$ of the population was vulnerable to impoverishment (Alemayehu and Addis 2014). ${ }^{4}$ Despite this high level of economic vulnerability, 98\% have access to electricity services (LSMS, 2015). ${ }^{5}$ However, many households receive electricity via shared connections, and services via private as well as shared electricity connections are unreliable. ${ }^{6}$

Addis Ababa's electricity services are provided by publicly owned utilities. Until 2013, Ethiopian Electric Power Corporation (EEPCO) provided electricity services to residential and nonresidential customers throughout Ethiopia, including Addis Ababa. In December 2013 EEPCO was split into in two independent public companies: Ethiopian Electric Power Company (EEP) is in charge of generation and transmission, and Ethiopian Electric Utility Company (EEU) is responsible for distribution. Most of EEP's generation is hydropower.7

In 2014 EEU adopted a seven-block IBT structure to calculate residential customers' monthly bills (Table 2). ${ }^{8}$ The tariff structure does not distinguish in its billing practices

\footnotetext{
${ }^{4}$ The Ministry of Finance and Economic Development of Ethiopia evaluated its poverty statistics on the basis of the total (absolute) poverty line and food poverty lines. The total poverty line per adult person per year corresponds to 6,866 Br 2015 in Constant Prices (value calculated for 2010/2011 Gregorian Calendar and adjusted for inflation, which corresponds to US\$332 in 2015 constant prices). 5 This suggests that from the perspective of access to electricity services (beneficiary incidence analysis), poor households do have access to electricity services. There is no evidence, however, that this is due to the way the IBT tariff structure targets subsidies.

${ }^{6}$ In the 2015 LSMS dataset, about $92 \%$ of households reported experiencing electricity interruption during the past 7 days. This is consistent with the data from our sample.

${ }^{7}$ In 2016 the installed electricity generating capacity in Ethiopia was about 4,304 MW (88\% hydropower; $12 \%$ other sources, including wind, geothermal, and diesel).

8 The electricity tariff in Ethiopia has undergone major changes in recent years. In the decades after 1959 it was a flat tariff rate with an average annual increase of about 5\% (although the tariff increased in some years and not in others). Tariff increases were not linked to inflationary or other
} 
between a private connection for exclusive use by a single household's members and a shared connection supplying multiple households.

EEU's tariff structure has three components: a minimum monthly charge, a fixed monthly charge, and a volumetric charge. From a global perspective this tariff structure is unusual, because both the minimum monthly charge and the fixed monthly charge vary as a function of the customer's monthly electricity use. The minimum monthly charge and the fixed monthly charge increase if monthly electricity use exceeds quantity thresholds (Table 2). ${ }^{9}$

[Table 2 about here]

\section{Data collection, sampling strategy, fieldwork}

\subsection{Collection of customer billing records from the electricity utility}

We obtained from EEU their complete set of monthly billing records for residential customers in metropolitan Addis Ababa for the one-year period from April 2015 through March 2016. These data included 7,778 million records, corresponding to one year of monthly bills for 649,000 "postpaid" residential customers. ${ }^{10}$ The billing records included

economic trends. During that period tariffs were differentiated by type of costumer and by type of system (self-contained or interconnected systems).

${ }^{9}$ The minimum monthly charge and the fixed monthly charge are both part of the algorithm used by the utility to calculate the monthly electricity bill for a connection. For each connection (private or shared) the utility calculates the appropriate fixed charge plus a charge for volumetric use. This total is then compared to the minimum charge associated with the volumetric use; the monthly bill for that connection is the greater of the two.

10 "Postpaid" customers (including 82\% of residential customers in Addis Ababa) pay their monthly bill for electricity service that has already been consumed. "Prepaid" consumers pay in advance. 
customers with connections for the exclusive use of family members and customers that shared the service with other households. Table 3 presents the information included in each customer's monthly electricity bill, including a customer identification number (account number). During the household survey, we collected this identification number from each household in the sample that had an EEU connection. We were thus able to match our household survey data with the billing records from EEU.

[Table 3 about here]

\subsection{Collection of information on costs of electricity services}

To calculate costs of providing electricity services, we collected EEU data on its capital costs, operation and maintenance $(\mathrm{O} \& \mathrm{M})$ costs, production levels, and losses during production and distribution. Information was obtained from various departments (e.g., Projects Office, Budgetary Control Office, and Finance Department) on the costs of generation, transmission, and distribution.

\subsection{Sampling}

The sampling frame for our household survey was EEU's postpaid residential customers. We drew a random sample of 660 EEU customers and were able to interview the head of household or spouse in each customer family. We posed a series of questions about the household's electricity service and use; socioeconomic, demographic, and housing characteristics; and other topics (see section 4.4, below). We asked the respondent whether the household shared its electricity connection with other households. Of the 660 
households, 497 (75\%) had EEU connections for exclusive use by household members; 163 (25\%) were providing electricity to other households who had no private account with EEU. In this latter case we attempted to interview all households that participated in each of the 163 shared connections, asking essentially the same set of questions we had posed to the account holders. The total number of households interviewed was 987 (660 households from the original sample plus an additional 327 households who obtained electricity from one of the 660 primary customers).

\subsection{Household questionnaire}

The survey instrument had twelve sections: one on demographics, nine sections about households' use of electricity service, and two sections on the household's socioeconomic characteristics. ${ }^{11}$ During the survey design, special attention was paid to key data to be used in our planned subsidy incidence analysis, especially household income and wealth; the matching of household data with EEU customer billing records; and the household's use (if any) of shared electricity connections. For households with shared connections, we included questions to determine the number of households sharing the bill, the mechanism used to share the bill, sharers' relation to the primary customer, and whether the primary EEU customer had imposed any restrictions on the use of electricity by households sharing the connection.

We also collected information on the geographic location of the house, including address and GPS coordinates, as well as the EEU customer identification numbers for households with accounts for electricity services.

11 We also collected data on household water use, but these findings are not presented in this paper. 


\subsection{Survey implementation}

A total of 20 enumerators and 4 field supervisors were deployed for the pilot tests and survey implementation. Three pilot tests were conducted in April 2016. The final survey was implemented from April 26 through May 25, 2016. If a sample household could not be interviewed, either because no one was home or the respondent was too busy at that time, enumerators returned up to two more times to try to conduct the interview. If the enumerator was unable to complete the interview after a total of three attempts, a replacement household from the same neighborhood was selected.

If the respondent was from a household with a primary EEU connection, the enumerator asked the respondent to show the household's most recent monthly electricity bill and recorded from it the customer identification number. This enabled us to verify that the household being interviewed was the same household that had been randomly selected and to match this sample household with its EEU customer billing record in our data files.

\section{Analytical framework: calculating the distribution of household subsidies, estimating costs of services}

\subsection{Basic subsidy incidence calculation}


This section describes how we estimated (1) the electricity subsidy received by each household in the sample and (2) the incidence of subsidies across the sample households. ${ }^{12}$ For each household in the sample, we calculated the subsidy it received for electricity service as the difference between the cost of supplying the household with electricity and the amount it paid for the service:

$S_{i}=\left(A C_{e} \times Q_{i}\right)-E X P_{i}$

where

$S_{i}=$ subsidy received by household $i$ for the service (US\$ per month);

$Q_{i}=$ household i's use of electricity per month (kWh per month);

$A C_{e}=$ total average cost of providing the electricity service in Addis Ababa (US\$ per $\mathrm{kWh}$;

$E X P_{i}=$ household $i$ 's monthly expenditure for electricity (US\$ per month).

Conceptually, the cost of providing electricity could be more or less than household i's expenditure, such that the household could either receive a subsidy or instead make a payment in excess of the cost of service provision. However, in our analysis the monthly cost of service $\left(A C_{e} \times Q_{i}\right)$ for every sample household was greater than its monthly expenditure for electricity service, i.e., all households in the sample received a subsidy.

Determining the incidence of the subsidies received by the sample households required a wealth indicator for each household. We used respondents' answers to our survey

12 Because we sampled from EEU's customers, all sample households received electricity services. The absence of households without electricity services in the sample is not a major limitation of our analysis because, as noted, $98 \%$ of households in Addis Ababa have EEU electricity service-either a private or shared connection. 
questions regarding asset ownership and housing characteristics to construct a wealth index using principal components analysis (Filmer and Pritchett, 2001, Filmer and Scott, 2008).13 The resulting wealth index score for each sample household allowed us to classify each household into one of five wealth quintiles, and to report the average electricity subsidies received by households in each wealth quintile. We also ranked all sample households by their wealth index scores and estimated a cumulative distribution of electricity subsidies by cumulative percentage of sample households.

\subsection{Calculation of electricity use and expenditure for households sharing connections}

For households with a private electricity connection we had the billing records from EEU to use as data for electricity use $\left(Q_{i}\right)$. For individual households with shared electricity connections, we did not have full records of metered electricity and monthly bills, only the records of the total metered electricity use and the monthly amount that EEU billed to the primary household account holder in the group. But because we had interviewed all households sharing each metered connection, we had comprehensive records of household size. To estimate $Q_{i}$ for each household $i$ in each shared group connection, we summed the total number of individuals in each household, and then of all individuals in each group; then divided each household total by the group total; and multiplied the metered electricity usage of the EEU primary customer $\left(Q_{E E U}\right)$ by that ratio.

$$
Q_{i}=Q_{E E U} \times\left[H_{H S i z e} /\left[\sum H_{H} \text { size }_{i} \text { of all households in group sharing electricity }\right]\right.
$$

\footnotetext{
${ }^{13}$ Appendix B presents the variables included in the wealth index and the principal component scores.
} 
where

$Q_{E E U}=$ metered electricity use by the group of households sharing the electricity meter; and

$H_{H S i z e}=$ number of members of household $i$ (including children).

\subsection{Electricity expenditure}

For households with a private electricity connection for the exclusive use of household members (i.e., not shared), we had the household's monthly expenditure $\left(E X P_{i}\right)$ as recorded in the customer billing records. For households using shared electricity connections, we estimated electricity expenditure on the basis of household size as a proportion of size of the total group using the connection. However, information from our survey revealed that shared electricity bills were not always divided among the participants according to household size. Our questionnaire results identified three types of households that shared a single metered connection: (1) the primary customer who holds the account and pays the bill to the utility company (33\% of these households); (2) neighbors or family who pay a flat rate or a percentage of the bill to the primary customer (23\%); and (c) tenants, who pay electricity through their house rent (44\%). Although our survey results indicated which of these categories applies to any given household, we did not learn the actual amount of every household's share of the bill or how it was calculated, primarily because tenants were uncertain about how electricity fees were accounted in their rents. To estimate the monthly expenditure of each sample household sharing an electricity connection $\left(E X P_{i}\right)$, we allocated an equal share of the total electricity bill to each household in the group: 


$$
E X P_{i}=\operatorname{Bill}_{E E U} \times[(1 / N],
$$

where

$N=$ the number of households in the group sharing the electricity meter; and

Bill $_{E E U}=$ amount billed by EEU to the primary customer sharing electricity with the group.

\subsection{Renters, restrictions on consumption, and implications for our subsidy incidence analysis}

Almost half of the sample households that were nonprimary electricity customers sharing a single metered connection with other households, were tenants of the primary electricity customer, who included electricity costs in tenants' monthly house rent. Nearly half of these tenants (44\%) reported that the landlord placed restrictions on their use of electricity. We thus surmised that they probably did not use as much electricity per household as the primary household. This conjecture was consistent with data from our household survey. We had asked households that shared connections if they thought that they consumed more, equal, or less electricity than other households that shared the same connection. Primary customers reported more often than other households that they believed that they used more electricity than others sharing the same metered connection. Our estimation strategy thus probably overestimates electricity usage among the poorest households (especially renters). This would result in an overestimation of the subsidy that poor households 
received. In other words, the poorest population probably receives an even lower share of the subsidy than our calculations suggest.

\subsection{Calculating the total average cost of electricity service}

Another critical parameter in the calculation of the subsidy received by each household $i$ for electricity service is $A C_{e}$, total average cost of providing electricity. We calculated $A C_{e}$ from data we had gathered from the utility company:

$A C_{e}=\left[\left(O M_{e}+K_{e}\right)+\right] /\left[P_{e}-L_{e}\right]$ and

$K_{e}=R_{e} \times \mathrm{OM}_{\mathrm{e}}$

where $O M$ is the annual value of operation and maintenance costs, $K_{e}$ is the annual capital cost, $R_{e}$ is the ratio of capital costs to $O M, P$ is the annual production level, and $L$ is the level of annual losses during production and distribution. ${ }^{14}$

All these data, for the years 2012-2015, were provided directly by various divisions within EEU: Budgetary Control Office, Finance Department, and Planning Department. In addition to the information on $O M$ and $R_{e}$, we also collected data on capital costs, which helped to

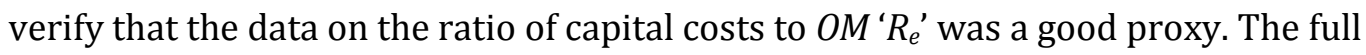
financial costs of electricity provision (including all investment costs) were estimated to be

\footnotetext{
${ }^{14}$ As seen in many other cases in the literature, electricity losses play a very important role in the calculation of costs; the higher the losses, the higher the average unit cost. In Addis Ababa, for the interval -, losses during provision of electricity were approximately $18 \%-22 \%$.
} 
95\% higher than $O M$ values. EEU also provided information on shares of capital costs on the different steps of generation, transmission, and distribution.

Table 4 presents our estimates of the total average cost of electricity services in Addis Ababa. We estimated this total average cost to be approximately US $\$ 0.09 / \mathrm{kWh}$, including US $\$ 0.004 / \mathrm{kWh}$ for O\&M costs and US $\$ 0.088 / \mathrm{kWh}$ for capital costs. ${ }^{15}$ These estimates of total average costs are far above all of the volumetric rates in the IBT structure. For example, the lifeline (lowest) rate for electricity (US $\$ 0.013 / \mathrm{kWh}$ ) is only $15 \%$ percent of the total average cost per kilowatt hour. The price in the highest-priced block only is $37 \%$ of the total average cost. Given that the prices in the highest blocks are far below total average costs, it is not surprising that the magnitude of the subsidies received by electricity customers in Addis Ababa is large. Appendix A presents additional details for our estimates on average unit costs of electricity services in Addis Ababa.

[Table 4 about here]

\section{Results}

\subsection{Monthly electric bills}

Table 5 presents the average monthly electricity use and electricity bills for the three groups of households in the sample: (1) households with a private, metered electricity

\footnotetext{
15 These average unit costs are comparable to estimates for other countries (see Table 1 for comparison cost data).
} 
connection for the exclusive use of family members (primary customer with private connection), (2) households that are account holders and share electricity with other households (primary customers with shared connection), and (3) households that are not primary customers but receive electricity from a primary customer via a metered connection shared with other households. Table 5 also presents the average household income and the monthly expenditure for electricity service as a percentage of monthly income for households in each of these three groups.

\section{[Table 5 about here]}

These summary results illustrate several points. First, there are almost as many households with shared connections who are not primary customers as there are households who are primary customers. Households with primary connections that share electricity on average share with three other households. Households with nonprimary connections comprise about two-thirds of the total households that share electricity connections.

Second, households with private connections for the exclusive use of family members (Group 1) use much more electricity than households with shared connections (Groups 2 and 3). Group 1 households on average used $256 \mathrm{kWh} /$ month, while Groups 2 and 3 combined are estimated to have used $104 \mathrm{kWh} /$ month. Group 2 households are estimated to have consumed more (136 kWh/month) than Group 3 households ( $89 \mathrm{kWh} /$ month), because on average they had larger families. However, even though our estimates for Group 2 and Group 3 take into account household size, they do not account for restrictions on electricity use that Group 2 households may have imposed on Group 3 households. 
Third, Group 1 households had substantially higher income (US\$360) than Groups 2 and 3, who shared electricity (US\$205). Once again, there is also a marked difference between households in Group 2 (monthly income US\$270) and Group 3 (monthly income US\$172). The ratio of monthly electricity expenditures to household income is low for all three groups, ranging from 1.1\% (Group 1) to 1.7\% (Group 3).

\subsection{Shared electricity consumption and shared bills}

Table 6 presents summary information on the number of households sharing electricity bills; the mechanisms used to share the bill (payment method); whether Group 3 households had any restrictions on electricity use; and the relation of Group 3 households to their respective primary customers (Group 2). In our sample, $66 \%$ of nonprimary households (Group 3) had charges for electricity included in their house rent, while the remaining households in Group 3 (34\%) either shared their bill in various ways or paid a fixed charge to the primary customer. One-third (33\%) of households in Group 3 reported having restrictions on their use of electricity services. As for Group 2, these primary customers who shared their connection with other households were somewhat more likely (55\%) to report that they consumed more electricity than others sharing the connection than households in Group 3 (6\%).

[Table 6 about here]

\subsection{Benefit Incidence of electric service subsidies}


Table 7 presents the main results of our electricity benefit incidence calculations. It shows the magnitude of the electricity subsidy received by households in each of five wealth quintiles, as well as the average across the entire sample. Figure 1 shows that the poorest wealth quintile received only $7 \%$ of the total electricity subsidy, whereas the wealthiest quintile received 37\%. Figure 2 shows that the great majority of Group 3 households (80\%) fell into the poorer quintiles, while the majority of Group 1 households fell into the wealthier quintiles (notably, 86\% of households in the fifth quintile are from Group 1).

\section{[Table 7 about here]}

[Figure 1 and Figure 2 about here]

Figure 3 presents the cumulative proportion of subsidies received by the proportion of households ranked by wealth. An effective scheme for targeting subsidies would be portrayed as a concave curve above the 45 -degree line. For example, if the poorest $10 \%$ of households received $90 \%$ of the subsidies, this would be depicted by a point in the far northwest portion of the figure. The 45-degree line indicates an equal distribution of subsidies, whereby the poorest $10 \%$ of households would receive $10 \%$ of the subsidies, $50 \%$ of the households would receive $50 \%$ of the subsidies, and so on. In contrast, the curve in figure 3, showing the distribution of electricity subsidies in Addis Ababa, is convex and portrays a highly unequal distribution of subsidies skewed toward middle- and upperincome households. For example, the poorest $50 \%$ of households (by wealth ranking) received only about $20 \%$ of the total subsidies even though an IBT structure is used to calculate electricity bills. 
[Figure 3 about here]

Figures 4 and 5 show the electricity bill and electricity subsidy as a percentage of household income by wealth quintile. In both figures, the leftmost vertical axis shows the monthly household income of the wealth quintiles and illustrates that the average household in the lowest wealth quintile had an average income of about US\$100 per month, while the average household in the highest wealth quintile had an average income of almost US\$600 per month. The rightmost vertical axis shows the percentage of household income represented by the electricity bill (Figure 4) or electricity subsidy (Figure 5). For households in the first through fourth wealth quintiles, the monthly electricity subsidy was approximately $5 \%$ of monthly income. However, for the richest quintile, the electricity subsidy was slightly more than $3 \%$ of income. ${ }^{16}$

[Figure 4 and Figure 5 about here]

\subsection{Reasons why IBTs do not target subsidies effectively to poor households}

Our results show that the majority of electricity subsidies are captured by upper- and middle-income households in Addis Ababa (Figure 1). This raises the question why the IBT structure used to price electricity services is not effectively targeting subsidies to poor

\footnotetext{
${ }^{16}$ We also collected self-reported data on income in our household survey. However, because income questions proved to be a sensitive topic for many households, we decided that our estimated wealth indicator was a more accurate reflection of household economic well-being than self-reported income.
} 
households. There are three main reasons why the city's electricity IBT structure is not working as planned.

First, the electricity used by residential customers was sold far below cost. Although some electricity use occurred in the higher-priced blocks, even the price in the highest IBT block fell far below total average costs. This means that the more electricity a household used, the more subsidies it received. Table 8 shows the percentage of sample households whose consumption fell in each tariff block of the electricity IBT.

[Table 8 about here]

Second, the rationale underpinning the IBT structure is that because wealthier households will use more electricity than poorer households, and the wealthiest households will fall in the upper blocks of the IBT plan, they will pay higher marginal and average prices than poorer households. The correlation between our wealth indicator and electricity use is $+0,63(\mathrm{p}$-value $=0.000) \cdot{ }^{17}$ This means that some poor households were using lots of electricity, and that some wealthy households were using low amounts of electricity. As a result, some poor households were paying higher average prices than wealthier households, and some wealthy households were paying very low marginal and average prices for the service. Figure 6 shows the distribution of electricity consumption among sample households by wealth quintile.

[Figure 6 about here]

17 The correlation between self-reported income and electricity use was only +0.27 (p-value $=0.000$ ). 
Third, because electricity prices were so far below total average costs, and the bills constituted such a small percentage of household income, it is likely that residential electricity customers in Addis Ababa did not respond to the marginal price in the block of the IBT into which their usage fell. Instead, they may simply have looked at their total bill and decided if it seemed reasonable. Or they may have divided the total of a shared bill by the quantity their own household owed, to determine the average price per share and thus to see if that appeared reasonable. In fact, we asked respondents in the survey if any member of the household checked the details of their electricity bill—and only $14 \%$ of respondents said that someone did. A sizable majority (73\%) said that they only checked the amount due on each monthly bill, and $14 \%$ admitted that their household neither reviewed the monthly consumption information nor questioned the amount due. If customers were responding to average instead of marginal prices, the IBT structure was sending an even lower price signal than envisaged. And because a household received more subsidies the more electricity it received, households' response to average rather than marginal prices would have exacerbated the poor targeting of subsidies.

\section{Conclusions and Policy Implications}

Our results show that in 2015/2016 the electricity subsidies received by households in Addis Ababa were large. The average household with a private electricity connection received a subsidy of US\$17.1 per month (about 4.8\% of household income). Households with shared connections received a much lower monthly subsidy, about US\$6.9 $3.4 \%$ of 
household income). Because our analysis included shared connections, we were able to show that electricity subsidies are even more regressive than previous analyses had suggested. The top quintile of the wealth distribution (the wealthiest $20 \%$ of households) received $37 \%$ of the subsidies, whereas the lowest quintile (the poorest $20 \%$ of households) received only $7 \%$ of the subsidies.

The regressive outcomes of the current IBT used to calculate electricity bills in Addis Ababa can be explained by two attributes of the tariff structure: (1) the volumetric rates in all blocks were substantially below the total average cost of delivery of the service; and (2) there was only a moderate association between electricity consumption and household wealth. Because prices were far below total average costs, electricity bills constituted only a very small percentage of household income.

Our analysis highlights the importance of two policy changes. First, the electricity tariff needs to be revised. IBT structure used to price electricity in Addis Ababa is not targeting subsidies effectively. Nor is it meeting cost recovery or economic efficiency objectives. It is unclear what price signal customers were perceiving from the tariff structure, but it certainly was not the correct signal to incentivize wise use of electricity.

Second, our analysis also highlights the need for means-tested customer assistance programs in which subsidies are delivered to poor, "hard to reach" households "outside the tariff." The IBT structure attempts to deliver subsidies to higher-income, richer primary customers with the hope that primary customers who share their electricity with other households will pass along a substantial share of the subsidies that they receive to households sharing their connection, either in the form of reduced electricity payments or 
lower rent. However, our analysis does not show that this is the case, and contrarily, it raises questions on whether richer households retain much of these subsidies rather than pass them on to poor, "hard-to-reach" households. If electricity tariffs are increased to meet cost recovery and economic efficiency objectives, special means-tested customer assistance programs are needed to ensure that poor, "hard-to-reach" households are able to afford essential electricity services.

\section{Acknowledgments}

We express great thanks to Alemu Mekonnen, Tensay Meles, Abebe Damte Beyene, and Samuel Abera, for their important contribution during the field work for data collection; to Gunnar Kohlin, Peter Martinson, and Mike Toman, who also contributed with feedback for the survey instrument; and to the World Bank for its financial support. 


\section{References}

Ahmed, F.; Trimble, C, and Yoshida, N. 2012. The transition from underpricing residential electricity in Bangladesh: Fiscal and distributional impacts. World Bank.

Angel-Urdiola, D., and Wodon, Q. 2005. Do utility subsidies reach the poor? Framework and evidence for Cape Verde." Poverty Reduction and Economic Management Department, Africa Region, World Bank.

Barde, J.A., Lehmann, P. 2014. Distributional effects of water tariff reforms: An empirical study for Lima, Peru. Water Resources and Economics 6: 30-57.

Fuente, D., Gakii Gatua, J., Ikiara, M., Kabubo-Mariara, J., Mwaura, M., and Whittington, D. 2016. Water and sanitation service delivery, pricing, and the poor: An empirical estimate of subsidy incidence in Nairobi, Kenya. Water Resources Research 52: 4845-62.

Filmer, D., and Pritchett, L. 2001. Estimating wealth effects without expenditure data-or tears: An application to educational enrollments in states in India. Demography 38(1): 115-32.

Filmer, D., and Scott, K. 2008. Assessing asset indices. World Bank Policy Research Paper 4605, World Bank.

Foster, V. 2004. "Toward a social policy for Argentina's infrastructure sectors: Evaluating the past and exploring the future. World Bank Policy Research, Working Paper 3422. World Bank.

Foster, V., and Araujo, C. 2004. Does infrastructure reform work for the poor? A case study from Guatemala. World Bank Policy Research. Working Paper 3185, World Bank.

Foster, V., and Yepes, T. 2006. Is cost recovery a feasible objective for water and electricity? The Latin American experience. World Bank Policy Research. Working Paper 3943. World Bank.

Gomez-Lobo, A., and D. Contreras. 2003. Water subsidy policies: A comparison of the Chilean and Colombian schemes. World Bank Economic Review 17(3): 391-407.

Groom, B.; Liu, X., Swanson, T., and Zhang, S. 2008. Resource pricing and poverty alleviation: The case of block tariffs for water in Beijing. in Coping With Water Deficiency, 48: 213-37, Springer, Dordrecht, Netherlands, DOI10.1007/978-1-4020-6615-3_9.

Komives, K., Halpern, J., Wodon, Q., and Foster. V. 2006. The distributional incidence of residential water and electricity subsidies. Unlisted: The World Bank, Policy Research Working Paper Series: 3878.

Komives, K., Johnson, T., and Halpern, J., 2009. Residential Electricity Subsidies in Mexico. Herndon, VA: The World Bank.

Lampietti, J. A., Gonzalez, H., Hamilton, E., and Wilson, M., 2003. Revisiting reform in the energy sector: Lessons from Georgia. Working Paper 21, World Bank. 
Living Starndards Measurement(LSMS), Data Set Ethiopia, 2015.

Mayer, K., Ghosh Banerjee, S., and Trimble, C. 2015. Elite capture : Residential tariff subsidies in India. Working Paper. World Bank.

Melendez, M. 2008. Subsidios al consumo de los servicios públicos: Reflexiones a partir del caso Colombiano. Working Paper. CAF.

Ministry of Finance and Economic Development of Ethiopia. 2012. Ethiopia's progress towards eradicating poverty: An interim report. March: 1-16.

Pattanayak, S., and Yang, J.-C.. 2002. Distributional incidence of water tariffs and subsidies in Kathmandu, Nepal. RTI International, Durham, NC.

Prokopy, S. 2002. Distributional incidence current and potential: Water tariffs and subsidies in Bangalore, India. RTI International, Durham, NC.

Trimble, C., Yoshida, N., and Saqib. N., 2011. Rethinking electricity tariffs and subsidies in Pakistan, World Bank working paper 32.

Walker, I., Ordonez, P., Serrano, P., and Halpern, J. 2000. Pricing subsides and the poor: Demand for improved water services in Central America. World Bank Policy Res. Pap. 2468, World Bank.

Wang, F., and Zhang, B. 2016. "Distributional incidence of green electricity price subsidies in China. Energy Policy 88: 27-38. DOI 10.1016/j.enpol.2015.09.035.

Wodon, Q., Ajwad, M. I., and Siaens, C. 2003. "Lifeline or means testing? Electric utility subsidies in Honduras. In Infrastructure for the Poor People: Public Policy for Private Provision, ed. P. Brook and T. Irwin, 227-96. Washington: World Bank and Public-Private Infrastructure Advisory Facility.

Whittington, D., Nauges, C., Fuente, D., and Wu, X. 2015. A diagnostic tool for estimating the incidence of subsidies delivered by water utilities in low- and medium-income countries, with illustrative simulations. Utilities Policy. DOI 10.1016/j.jup.2014.12.007. 


\section{Appendices}

\section{Appendix A. Estimation of Average Unit Cost of Electricity Provision}

\section{Facts about electricity generation in Ethiopia}

1, Almost $80 \%$ of the installed capacity and $91 \%$ of average energy generated come from hydropower plants. The remaining installed capacity and average energy are from other sources (including diesel, geothermal, and wind).

2. For comparison, the long run marginal cost (LRMC) calculated in the "Master Plan Study for the Ethiopian Power System Expansion' was 0.084 USD/KWh (at a typical load factor of $65 \%$ and with a discount rate of $10 \%$ ) and 0.109 USD/KWh (at a load factor of $65 \%$ and discount rate of $12 \%$ ).

[Table A.1 about here]

Key assumptions:

Percentage of O\&M costs from total capital costs: $5 \%$

Percentage of CAPEX distribution costs in total capital costs: $25 \%$

Percentage of CAPEX transmission costs in total capital costs: $15 \%$

Percentage of CAPEX generation costs in total capital costs: $60 \%$

Transmissions losses (4\%)

Distribution losses (10\%-12\%)

${ }^{\mathrm{a}} \mathrm{GC}=$ Gregorian Calendar, EC = Ethiopian Calendar

${ }^{\mathrm{b}}$ Data collected from the EEP and EEU from the Budget and Planning Departments

c Estimates based on the reference percentages from the Ethiopian Electricity Utility Company's Master

Plan

${ }^{\mathrm{d}, \mathrm{e}}$ Costs shown in this table take into account all costs of generation and delivery, including costs of energy and power.

e The data collected at the EEU and EEP Budgetary and Financial Departments included disaggregated data on the three processes of generation, transmission and distribution, as well as data on transmission and distribution losses. We consider the annual O\&M cost data to be reliable. The data on capital costs differed among departments; however, they provided a good idea of the type of costs incurred for power plant construction. Nevertheless, the data on capital costs were not enough to calculate the NPV for all facilities in operation at a specific year. For this reason, the estimation strategy was to rely on percentages of costs between OPEX and CAPEX, and then on percentages of capital expenditures for the three processes of electricity delivery (generation, transmission and distribution) among the overall capital costs. We believe this estimation strategy provided reasonable estimates of the average unit cost. 


\section{Appendix B. Wealth Index}

The wealth index that we constructed uses the principal component analysis. We followed the standard methodology from Filmer and Pritchett (2001) and Filmer and Scott (2008). The best results use the first component, which has an eigenvalue of 4.84 and explains $25.5 \%$ of variation in variables that we include in our index. Table A2 includes the factor scores for every variable included in the wealth index.

[Table B.1 about here] 
Table 1. Literature Review of Subsidy Incidence Case Studies of Electricity Provision from Developing Countries [continues, further columns are shown next page]

\begin{tabular}{|c|c|c|c|c|c|c|c|}
\hline Author(s) & Country & Area & $\begin{array}{l}\text { Year of } \\
\text { study }\end{array}$ & $\begin{array}{c}\text { Type of tariff } \\
\text { structure at time of study }\end{array}$ & $\begin{array}{c}\text { Type of data } \\
\text { on consumption }\end{array}$ & $\begin{array}{c}\text { Cost } \\
\text { estimation }\end{array}$ & 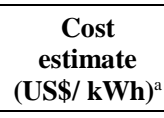 \\
\hline $\begin{array}{l}\text { Mayer, Banerjee, } \\
\text { and Trimble (2015) }\end{array}$ & India & national & $\begin{array}{l}\text { 2004-2005, } \\
2009-2010\end{array}$ & $\begin{array}{l}\text { Majority use IBT. (several utility } \\
\text { companies and regions in the } \\
\text { country). }\end{array}$ & $\begin{array}{c}\text { Self-reported } \\
\text { (from household survey) }\end{array}$ & $\begin{array}{c}\text { Reference estimate: } \\
\text { aggregate measure of } \\
\text { expenditure } \\
\text { by state and net input of energy }\end{array}$ & 0.06 \\
\hline $\begin{array}{l}\text { Trimble, Yoshida, } \\
\text { and Saqib (2011) }\end{array}$ & Pakistan & national & 2008-2011 & 4-block IBT & $\begin{array}{c}\text { Self-reported } \\
\text { (from household survey) }\end{array}$ & $\begin{array}{c}\text { Costs of supply } \\
\text { vary dependent on fuel price } \\
\text { (reference from utilty } \\
\text { company) }\end{array}$ & 0.09 \\
\hline $\begin{array}{l}\text { Komives et al. } \\
\text { ( 2009) }\end{array}$ & Mexico & national & 2003-2006 & Majority use IBT & $\begin{array}{c}\text { Self-reported } \\
\text { (electricity expenditures from } \\
\text { household survey) }\end{array}$ & $\begin{array}{l}\text { Include all production costs. } \\
\text { reported by utility companies }\end{array}$ & 0.16 \\
\hline $\begin{array}{l}\text { Lampietti et al. } \\
\text { (2003) }\end{array}$ & Georgia & Tbilisi & 2001 & Means-tested & $\begin{array}{l}\text { Billing records from utility } \\
\text { company }\end{array}$ & State Dept. reference & 0.06 \\
\hline Wodon et al. (2003) & Honduras & National & 1999 & $\begin{array}{l}\text { 4-block IBT with } \\
300 \mathrm{kWh} \text { threshold }\end{array}$ & $\begin{array}{c}\text { Self-reported } \\
\text { household survey data }\end{array}$ & n.r..$^{c}$ & n.r. ${ }^{c}$ \\
\hline $\begin{array}{l}\text { Angel-Urdiola and } \\
\text { Wodon (2005) }\end{array}$ & $\begin{array}{l}\text { Cape Verde } \\
\text { Sao Tome } \\
\text { Rwanda }\end{array}$ & $\begin{array}{l}\text { National } \\
\text { and urban in } \\
\text { Rwanda }\end{array}$ & 2001-2002 & $\begin{array}{c}\text { Cape Verde: } \\
\text { 2-block IBT } \\
\text { Sao Tome: } \\
\text { 3-block IBT } \\
\text { Rwanda: Uniform volumetric } \\
\text { tariff }\end{array}$ & $\begin{array}{c}\text { Self-reported } \\
\text { household survey data }\end{array}$ & 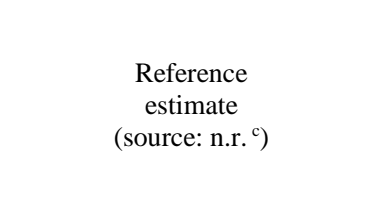 & 0.17 \\
\hline $\begin{array}{l}\text { Ahmed, Trimble and } \\
\text { Yoshida (2012) }\end{array}$ & Bangladesh & National & 2010-2012 & $\begin{array}{l}\text { 3-block IBT } \\
\text { (urban areas) } \\
\text { 4-block IBT } \\
\text { (rural areas) }\end{array}$ & $\begin{array}{c}\text { Self-reported } \\
\text { household survey expenditure } \\
\text { data }\end{array}$ & 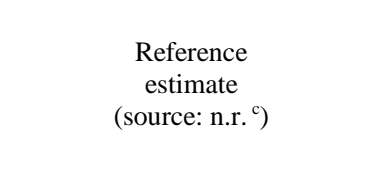 & 0.054 \\
\hline
\end{tabular}




\begin{tabular}{|c|c|c|c|c|}
\hline $\begin{array}{c}\text { Analysis by } \\
\text { Connection Type } \\
\text { shared vs. private }\end{array}$ & $\begin{array}{l}\text { Estimated } \\
\text { Subsidy }\end{array}$ & Estimated share of total subsidies & $\begin{array}{c}\text { Type of subsidy } \\
\text { distribution }\end{array}$ & $\begin{array}{l}\text { Magnitude } \\
\text { of Subsidy }{ }^{b}\end{array}$ \\
\hline No & $\begin{array}{l}0.024(\mathrm{US} \$ \text { / } \\
\mathrm{kWh})\end{array}$ & $\begin{array}{l}87 \% \text { subsidies } \\
\text { go to above poverty line population. } \\
\text { Poorest quintile: } 14 \%\end{array}$ & Regressive & $\begin{array}{c}87 \% \text { of all national } \\
\text { residential } \\
\text { consumption } \\
\text { subsidized } \\
\text { In } 2010=\text { US } \$ 3.6 \\
\text { billion } \\
(0.4 \% \text { of GDP }) \\
\end{array}$ \\
\hline No & n.r. ${ }^{c}$ & $\begin{array}{l}\text { Richest quintile: } \\
40 \% \text { to } 29 \% \text { (between } 2008 \text { and 2011) }\end{array}$ & Regressive & $\begin{array}{c}90 \% \text { of residential } \\
\text { consumption } \\
\text { subsidized }\end{array}$ \\
\hline No & $\begin{array}{l}0.094 \\
\text { (US\$ / } \\
\mathrm{kWh})\end{array}$ & $\begin{array}{l}\text { (Varies, depending on the } \\
\text { tariff), majority are: } \\
\text { Poorest } 3 \text { deciles: } 15 \%-20 \% \\
\text { Richest } 3 \text { deciles: } 39 \%\end{array}$ & Regressive & $\begin{array}{c}\text { In } 2006= \\
\text { US } \$ 9 \text { billion } \\
(0.7 \% \text { of GDP) }\end{array}$ \\
\hline No & $\begin{array}{l}40 \mathrm{kWh}- \\
80 \mathrm{kWh}\end{array}$ & $\begin{array}{c}\text { Year } 2000 \\
\text { Poorest quintile: } 25 \% \\
\text { Richest quintile: } 10 \% \\
\text { Year 2001 } \\
\text { Poorest quintile: } 27 \% \\
\text { Richest quintile: } 14 \%\end{array}$ & $\begin{array}{l}\text { Progressive } \\
\text { (A high } \\
\text { share still goes to the } \\
\text { top quintiles) }\end{array}$ & n.r. ${ }^{c}$ \\
\hline No & n.r. ${ }^{c}$ & $\begin{array}{l}60 \% \text { of households that are } \\
\text { non-poor receive the subsidy, } 23 \% \text { of households } \\
\text { that are poor receive the subsidy. Ratio of poor to } \\
\text { non-poor beneficiaries of subsidy is } 0.39\end{array}$ & Regressive & $\begin{array}{l}17.5 \text { million } \\
(0.34 \% \text { of GDP })\end{array}$ \\
\hline No & n.r. ${ }^{c}$ & $\begin{array}{l}\text { Share of the subsidy benefits } \\
\text { received by the poor divided } \\
\text { by the proportion of the } \\
\text { population in poverty: } \\
0.48 \text { Cape Verde } \\
\text { 0.40 Sao Tome, } 0.39 \text { Rwanda }\end{array}$ & Regressive & n.r. ${ }^{c}$ \\
\hline No & $\begin{array}{c}0.017 \\
(\mathrm{US} \$ / \mathrm{kWh})\end{array}$ & $\begin{array}{l}\text { Poorest quintile: } 6 \% \\
\text { Richest quintile: } 42 \%\end{array}$ & Regressive & $\begin{array}{l}0.2 \% \text { of GDP in } 2010 \\
0.8 \% \text { of GDP in } 2012\end{array}$ \\
\hline
\end{tabular}

${ }^{a}$ Expressed in US dollars of the year the subsidy was analyzed in the reporting study. Calculated using the data from each study deflated by the average exchange rate from the

World Bank development indicators for that year.

b Total subsidy costs from study and relation to national GDP from study, when available. If this is not available, \% of GDP is calculated based on World Bank figures.

${ }^{c}$ n.r. $=$ not reported 
Table 2. Tariff Structure for Electricity Provision Services in Addis Ababa, 2015-2016

\begin{tabular}{ccccccc}
\hline \multicolumn{2}{c}{ Consumption charge } & \multicolumn{2}{c}{$\begin{array}{c}\text { Fixed monthly charge for } \\
\text { service }\end{array}$} & \multicolumn{2}{c}{ Minimum charge } \\
\hline $\begin{array}{c}\text { Tariff } \\
\text { block }\end{array}$ & $\begin{array}{c}\text { Monthly } \\
\text { consumption } \\
(\mathrm{kWh})\end{array}$ & $\begin{array}{c}\text { Tariff } \\
(\mathrm{US} \$ \mathrm{kWh})\end{array}$ & $\begin{array}{c}\text { Monthly } \\
\text { consumption } \\
(\mathrm{kWh})\end{array}$ & $\begin{array}{c}\text { Tariff } \\
(\mathrm{US} \$)\end{array}$ & $\begin{array}{c}\text { Monthly } \\
\text { consumption } \\
(\mathrm{kWh})\end{array}$ & $\begin{array}{c}\text { Tariff } \\
(\text { US\$) }\end{array}$ \\
\hline Block 1 & $0-50$ & 0.0132 & $0-25$ & 0.068 & $0-20$ & 2.03 \\
Block 2 & $51-100$ & 0.0172 & $26-50$ & 0.165 & $20-220$ & 0.98 \\
Block 3 & $101-200$ & 0.0241 & $51-105$ & 0.330 & 100000000 & 0.49 \\
Block 4 & $201-300$ & 0.0266 & $106-300$ & 0.495 & & \\
Block 5 & $301-400$ & 0.0274 & $>300$ & 0.660 & & \\
Block 6 & $401-500$ & 0.0284 & & & & \\
Block 7 & $>500$ & 0.0336 & & & & \\
\hline
\end{tabular}

- Fixed charge that changes dependent upon the range of household monthly consumption. 
Table 3. Customer information on a household electricity bill obtained from EEU

\begin{tabular}{|c|c|}
\hline \multirow{3}{*}{ Identification } & Electricity bill \\
\hline \multirow{2}{*}{ Date of service } & Customer ID \\
& $\begin{array}{c}\text { Customer name } \\
\text { Address }\end{array}$ \\
\hline \multirow{5}{*}{ Billing information } & Month, year \\
& Consumption level \\
& Total bill amount \\
& Consumption charge \\
& Service charge \\
& Minimum charge \\
& Connection fees \\
& Inspection fees \\
\hline
\end{tabular}


Table 4. Summary of Average Unit Costs for Electricity, Addis Ababa, 2015-2016

\begin{tabular}{lc}
\hline Cost component by type of cost & $\begin{array}{c}\text { Electricity } \\
\text { (US\$/kWh) }\end{array}$ \\
\hline Operation and Maintenance & \\
Capital & 0.004 \\
Total costs & 0.088 \\
Cost component by production step & 0.092 \\
Distribution & \\
Transmission & 0.023 \\
Generation & 0.014 \\
Total costs & 0.055 \\
\hline Source: Authors' calculations based on primary data collected from the utility company \\
(US\$ = 20.68 Br)
\end{tabular}


Table 5. Residential Electricity Monthly Consumption, Payment and Subsidy by Type of Connection, Addis Ababa, 2016

\begin{tabular}{lcccc}
\hline & $\begin{array}{c}\text { Private } \\
\text { Electricity } \\
\text { Connection } \\
\text { (Group 1) }\end{array}$ & $\begin{array}{c}\text { Shared } \\
\text { Electricity } \\
\text { Connection }\end{array}$ & \multicolumn{2}{c}{ Shared Electricity Connection } \\
\cline { 5 - 6 } & 497 & 490 & $\begin{array}{c}\text { Primary } \\
\text { Customer } \\
\text { (Group 2) }\end{array}$ & $\begin{array}{c}\text { Non-primary } \\
\text { Customer } \\
\text { (Group 3) }\end{array}$ \\
\hline No. Observations (households) & 4.8 & 3.2 & 4.3 & 327 \\
\hline Average household size & 256 & 104 & 136 & 2.7 \\
\hline Average electricity use (kWh) & 6.0 & 2.5 & 3.6 & 89 \\
\hline Average electricity bill (US\$) & 17.1 & 6.9 & 9.0 & 2.0 \\
\hline $\begin{array}{l}\text { Average monthly subsidy } \\
\text { received (USD\$) }\end{array}$ & 360 & 205 & 270 & 172 \\
\hline $\begin{array}{l}\text { Household monthly income } \\
\text { (US\$) }\end{array}$ & $1.7 \%$ & $1.2 \%$ & $1.3 \%$ & $1.1 \%$ \\
\hline $\begin{array}{l}\text { Electricity bill as percentage } \\
\text { of household income }\end{array}$ & $4.8 \%$ & $3.4 \%$ & $3.3 \%$ & $3.4 \%$ \\
\hline $\begin{array}{l}\text { Electricity subsidy as a } \\
\text { percentage of household } \\
\text { income }\end{array}$ & & & & \\
\hline
\end{tabular}

Source: Household survey data matched to utility billing records. 
Table 6. Types of Payment Methods for Households that Share Electricity Meters, Addis Ababa, 2016

\begin{tabular}{|c|c|c|c|c|c|c|}
\hline Payment Method & Freq. & Percent & $\begin{array}{c}\text { Average } \\
\text { number of } \\
\text { households } \\
\text { with } \\
\text { shared } \\
\text { connection }\end{array}$ & $\begin{array}{c}\text { Restrictions } \\
\text { on use of } \\
\text { resource }\end{array}$ & $\begin{array}{l}\text { Households that } \\
\text { think they } \\
\text { consume more } \\
\text { than other } \\
\text { households on } \\
\text { same metered } \\
\text { connection } \\
\end{array}$ & $\begin{array}{l}\text { Relation to } \\
\text { primary } \\
\text { customer }\end{array}$ \\
\hline Primary customer & 162 & $33 \%$ & 3.01 & - & $55 \%$ & - \\
\hline $\begin{array}{l}\text { Included in the house } \\
\text { rent }\end{array}$ & 215 & $44 \%$ & 4.62 & $44 \%$ & $4 \%$ & $\begin{array}{c}\text { tenant: } 82 \% \\
\text { neighbor/relative: } 18 \%\end{array}$ \\
\hline Sharing bill & 57 & $12 \%$ & 2.86 & $14 \%$ & $10 \%$ & $\begin{array}{c}\text { tenant: } 14 \% \\
\text { neighbor/relative: } 86 \%\end{array}$ \\
\hline Flat rate & 47 & $10 \%$ & 5.68 & $12 \%$ & $12 \%$ & $\begin{array}{c}\text { tenant: } 51 \% \\
\text { neighbor/relative: } 49 \%\end{array}$ \\
\hline $\begin{array}{l}\text { Did not report payment } \\
\text { method }\end{array}$ & 9 & $2 \%$ & 2.55 & - & - & - \\
\hline
\end{tabular}


Table 7. Electricity Subsidy by Wealth Quintiles, Addis Ababa, 2016

\begin{tabular}{lcccccc}
\hline \multicolumn{1}{c}{ Quintile } & $\mathbf{1}$ & $\mathbf{2}$ & $\mathbf{3}$ & $\mathbf{4}$ & $\mathbf{5}$ & $\begin{array}{c}\text { All } \\
\text { Quintiles }\end{array}$ \\
\hline $\begin{array}{l}\text { Household Income } \\
\text { Q }\end{array}$ & 119 & 152 & 223 & 315 & 544 & 304 \\
\hline $\begin{array}{l}\text { Average monthly } \\
\text { subsidy } \\
\text { received (USD\$) }\end{array}$ & 5.6 & 8.3 & 12.0 & 15.6 & 19.1 & 13.4 \\
\hline $\begin{array}{l}\text { Total subsidy as } \\
\text { percentage } \\
\text { of household income }\end{array}$ & $4.7 \%$ & $5.4 \%$ & $5.4 \%$ & $4.9 \%$ & $3.5 \%$ & $4.4 \%$ \\
\hline
\end{tabular}


Table 8. Percentage of Sample in Each Tariff Block of the Electricity IBT Addis Ababa, 2016

\begin{tabular}{|c|c|c|c|}
\hline Block no. & $\begin{array}{c}\text { Private } \\
\text { connections }\end{array}$ & $\begin{array}{c}\text { Shared } \\
\text { connections }\end{array}$ & Total \\
\hline \multirow{2}{*}{$1(0-50 \mathrm{kWh})$} & 25 & 10 & 35 \\
\hline & $3 \%$ & $1 \%$ & $4 \%$ \\
\hline \multirow{2}{*}{$2(>50-100 \mathrm{kWh})$} & 52 & 30 & 82 \\
\hline & $5 \%$ & $3 \%$ & $8 \%$ \\
\hline \multirow{2}{*}{$3(>100-200 \mathrm{kWh})$} & 131 & 125 & 256 \\
\hline & $13 \%$ & $13 \%$ & $26 \%$ \\
\hline \multirow{2}{*}{$4(>200-300 \mathrm{kWh})$} & 117 & 115 & 232 \\
\hline & $12 \%$ & $12 \%$ & $24 \%$ \\
\hline \multirow{2}{*}{$5(>300-400 \mathrm{kWh})$} & 87 & 88 & 175 \\
\hline & $9 \%$ & $9 \%$ & $18 \%$ \\
\hline \multirow{2}{*}{$6(>400-500 \mathrm{kWh})$} & 48 & 43 & 91 \\
\hline & $5 \%$ & $4 \%$ & $9 \%$ \\
\hline \multirow{2}{*}{7 (ç500 kWh) } & 37 & 79 & 116 \\
\hline & $4 \%$ & $8 \%$ & $12 \%$ \\
\hline \multirow{2}{*}{ Total } & 497 & 490 & 987 \\
\hline & $50.4 \%$ & $49.6 \%$ & $100 \%$ \\
\hline
\end{tabular}


Table A.1: Average Unit Cost of Electricity Provision in Ethiopia (US\$ 2015 Constant Prices)

\begin{tabular}{|c|c|c|c|c|}
\hline & & $2011 / 2012 \mathrm{GC}^{\mathrm{a}}$ & 2012/2013 GC & 2013/2014 GC \\
\hline & & $2004 \mathrm{EC}$ & 2005 EC & \\
\hline \multirow{4}{*}{$\begin{array}{l}\text { O\&M costs }{ }^{\mathrm{b}, \mathrm{c}, \mathrm{e}} \\
\text { (Thousand US\$) }\end{array}$} & Distribution & 9,848 & 9,427 & 8,059 \\
\hline & Transmission & 4,263 & 5,600 & 5,752 \\
\hline & Generation & 11,600 & 22,972 & 21,479 \\
\hline & Total & 25,711 & 37,999 & 35,290 \\
\hline \multirow{4}{*}{$\begin{array}{l}\text { Capital costs }{ }^{\mathrm{d}, \mathrm{e}} \\
\text { (Thousand US\$) }\end{array}$} & Distribution & 128,555 & 189,996 & 176,451 \\
\hline & Transmission & 77,133 & 113,998 & 105,871 \\
\hline & Generation & 308,532 & 455,991 & 423,483 \\
\hline & Total & 514,220 & 759,985 & 705,804 \\
\hline $\begin{array}{l}\text { Annual production } \\
(\mathrm{GWh})\end{array}$ & & 6,277 & 7,577 & 8,692 \\
\hline $\begin{array}{l}\text { O\&M average cost } \\
\text { (US\$/kWh) }\end{array}$ & & 0.004 & 0.005 & 0.004 \\
\hline $\begin{array}{l}\text { Capital average cost } \\
\text { US } \$ / k W h\end{array}$ & & 0.082 & 0.100 & 0.081 \\
\hline $\begin{array}{l}\text { Total Average Cost } \\
\text { (US\$/kWh) }\end{array}$ & & 0.086 & 0.105 & 0.085 \\
\hline
\end{tabular}


Table B.1: Factor Scores of Variables Included in Wealth Index

\begin{tabular}{ll}
\hline Variable & Factor Scores \\
\hline House ownership & 0.227 \\
Electric injera & 0.294 \\
Use of biomass & -0.107 \\
Number of phones per adult & 0.104 \\
TV & 0.198 \\
Computer & 0.241 \\
Car & 0.253 \\
Laundry machine & 0.229 \\
Water heater & 0.285 \\
Refrigerator & 0.323 \\
Additional house & 0.125 \\
Separate kitchen & 0.237 \\
Toilet inside home & 0.224 \\
Use of piped drinking water & 0.163 \\
Use of public tap water & -0.192 \\
Private tap in household & 0.285 \\
Consumption of bottled water & 0.045 \\
Low quality materials of dwelling & -0.226 \\
Number of room in dwelling & 0.348 \\
\hline & \\
\hline &
\end{tabular}
$n=988 \mathrm{obs}$ 


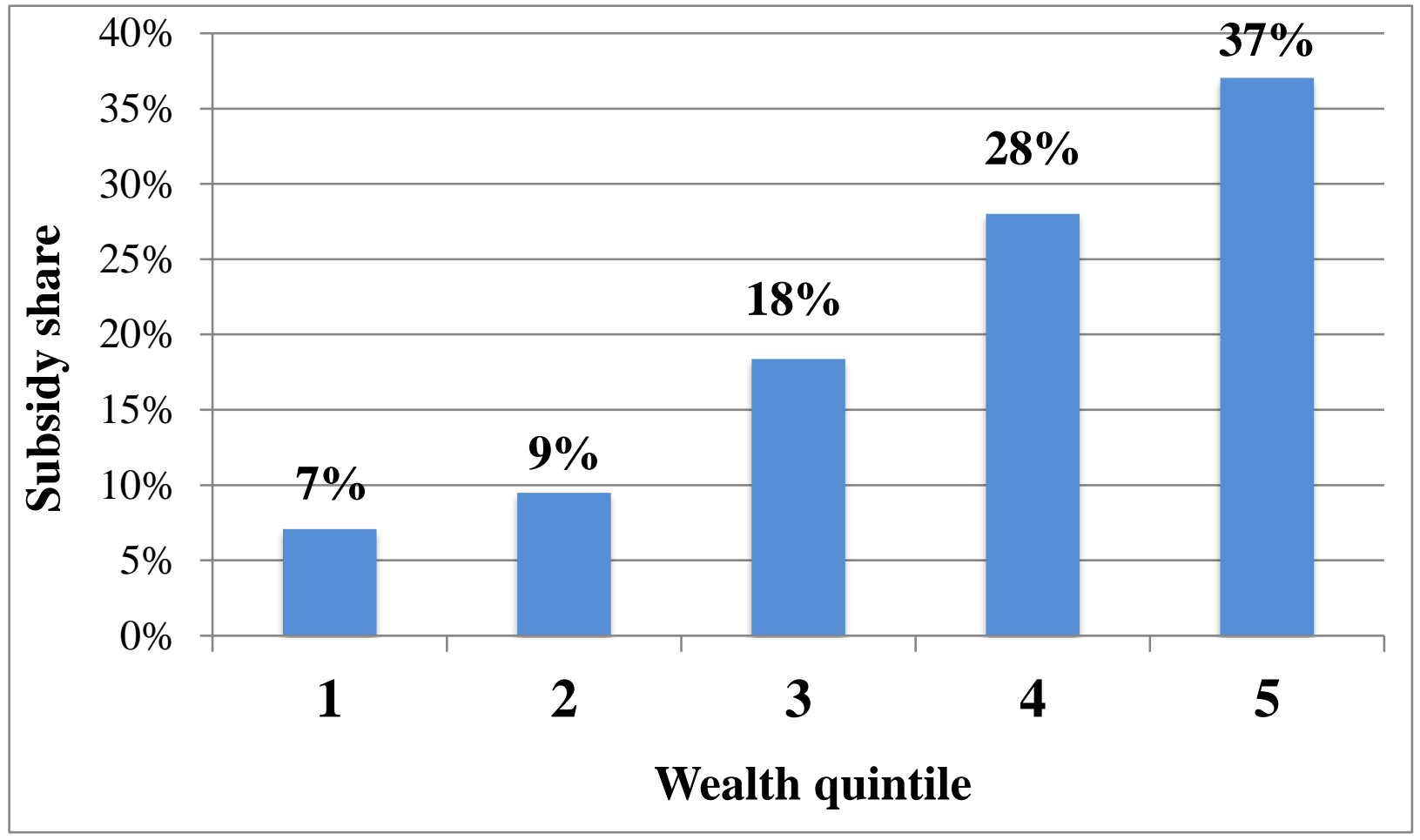

Figure 1. Electricity Subsidy Share by Wealth Quintile, Addis Ababa, 2016 


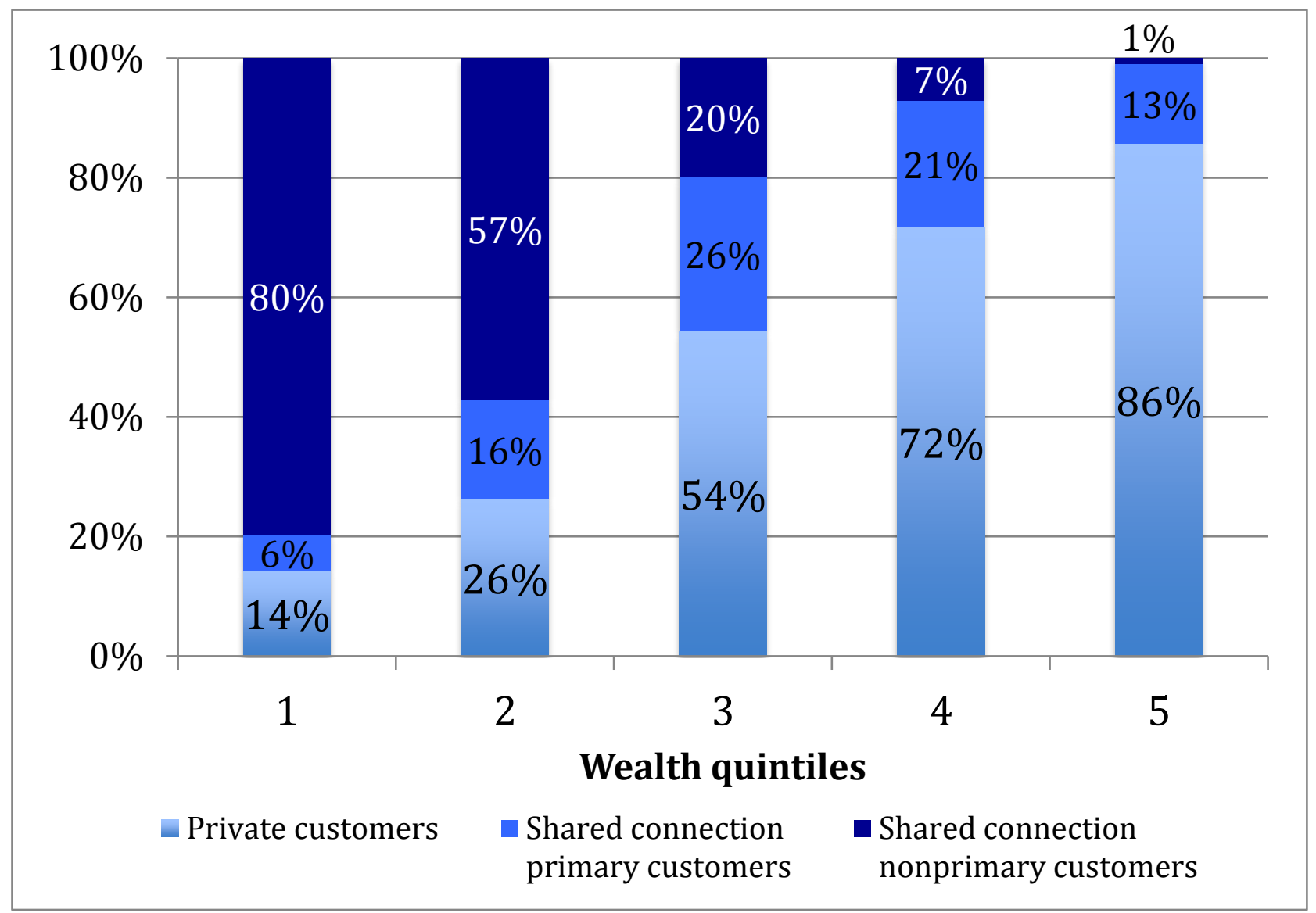

Figure 2. Private and Shared Electricity Connections by Wealth Quintile, Addis Ababa, 2016 


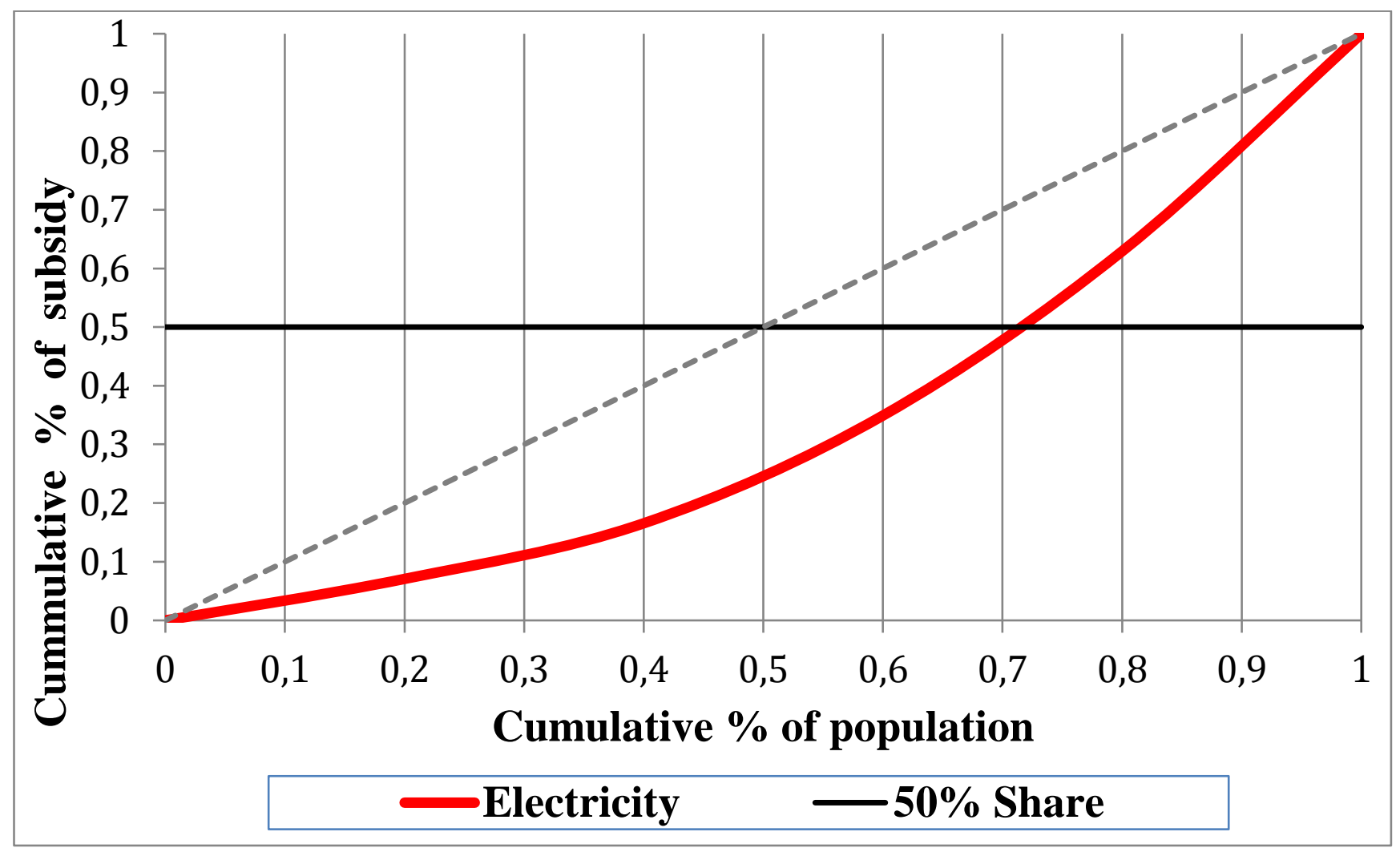

Figure 3. Cumulative Percentages of electricity subsidies by Wealth Ranking, Addis Ababa, 2016 


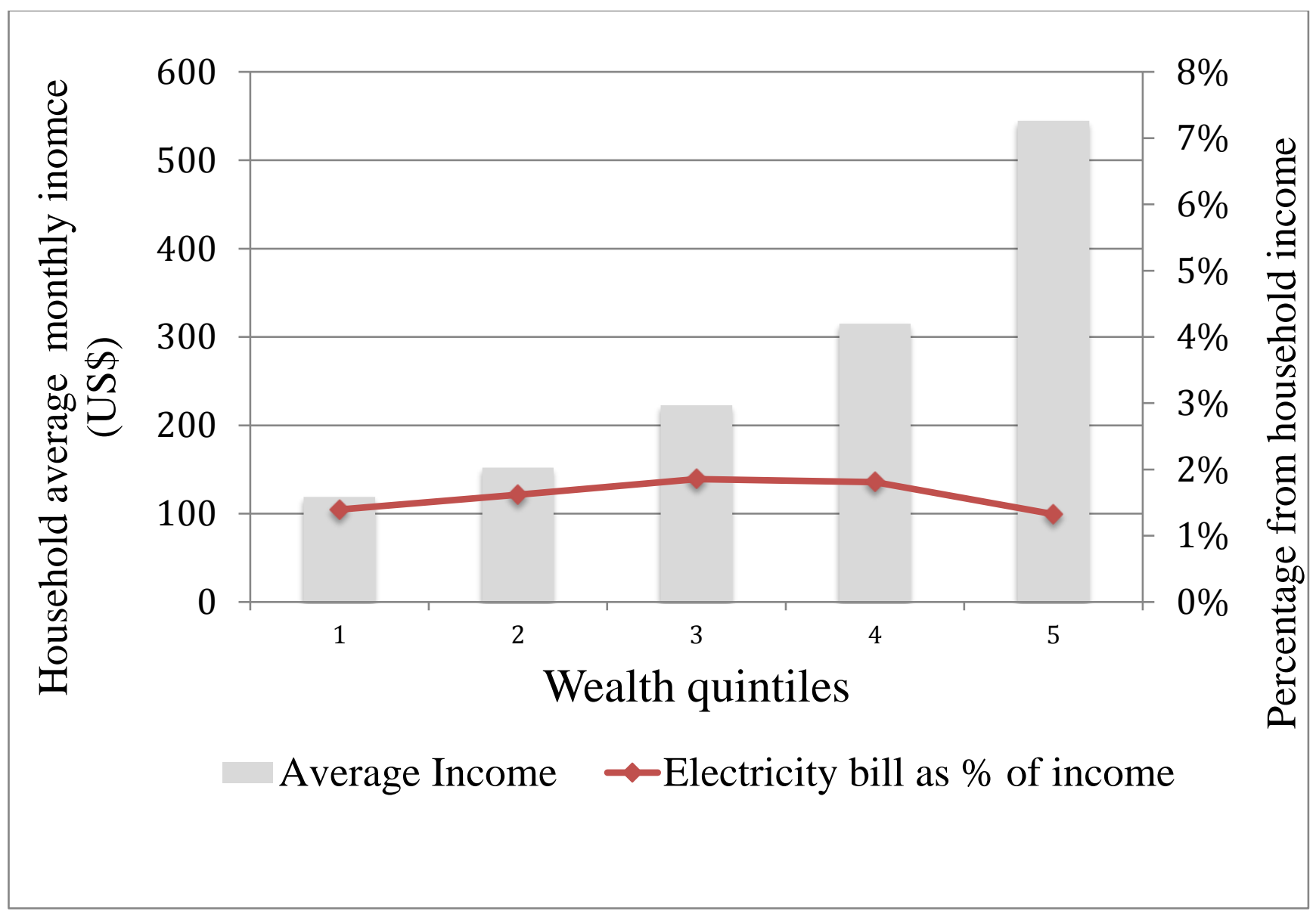

Figure 4. Electricity Bill as Percentage of Income, by Wealth Quintiles, Addis Ababa, 2016 


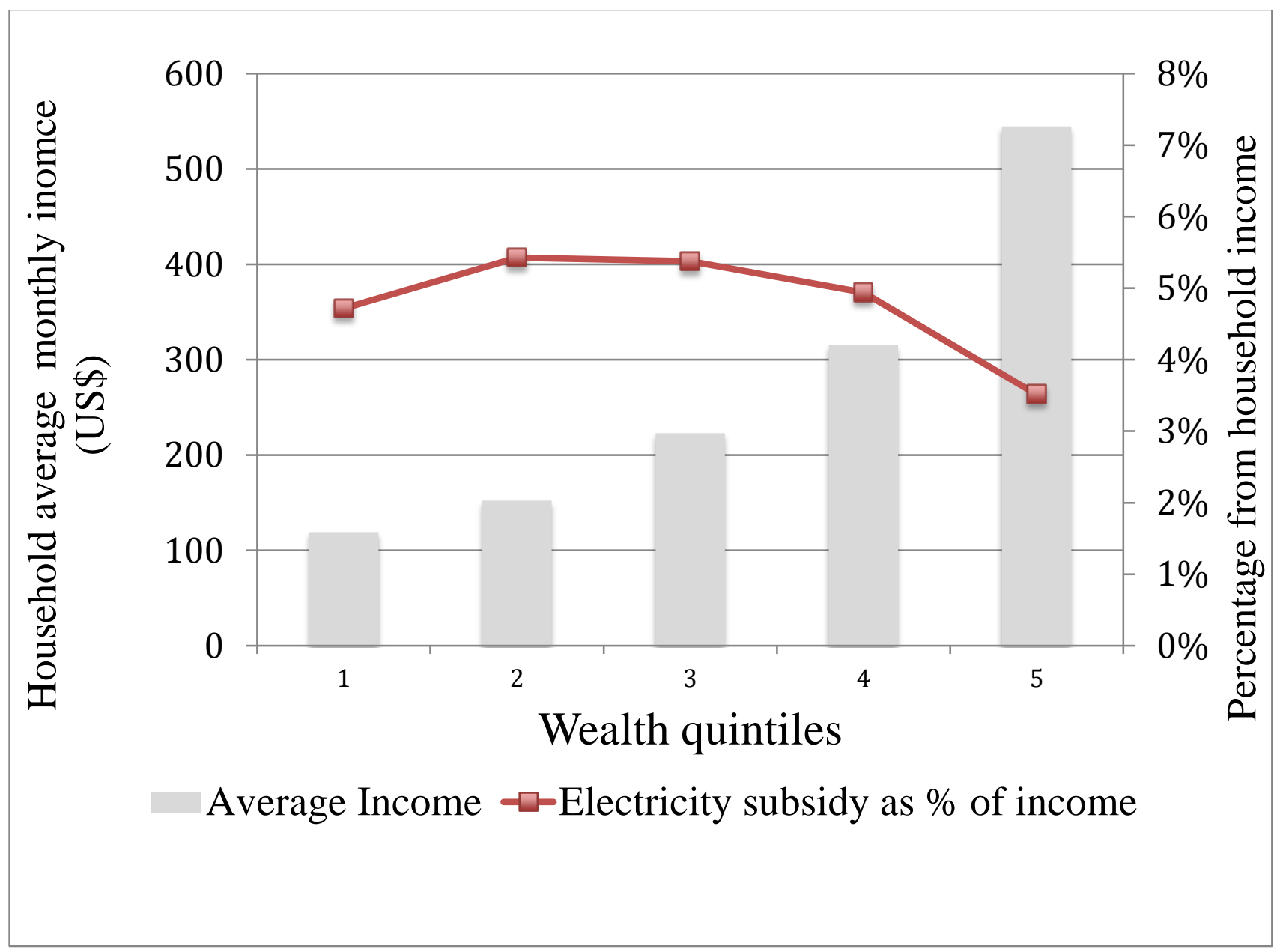

Figure 5. Electricity Subsidy as Percentage of Income, by Wealth Quintiles, Addis Ababa, 2016 


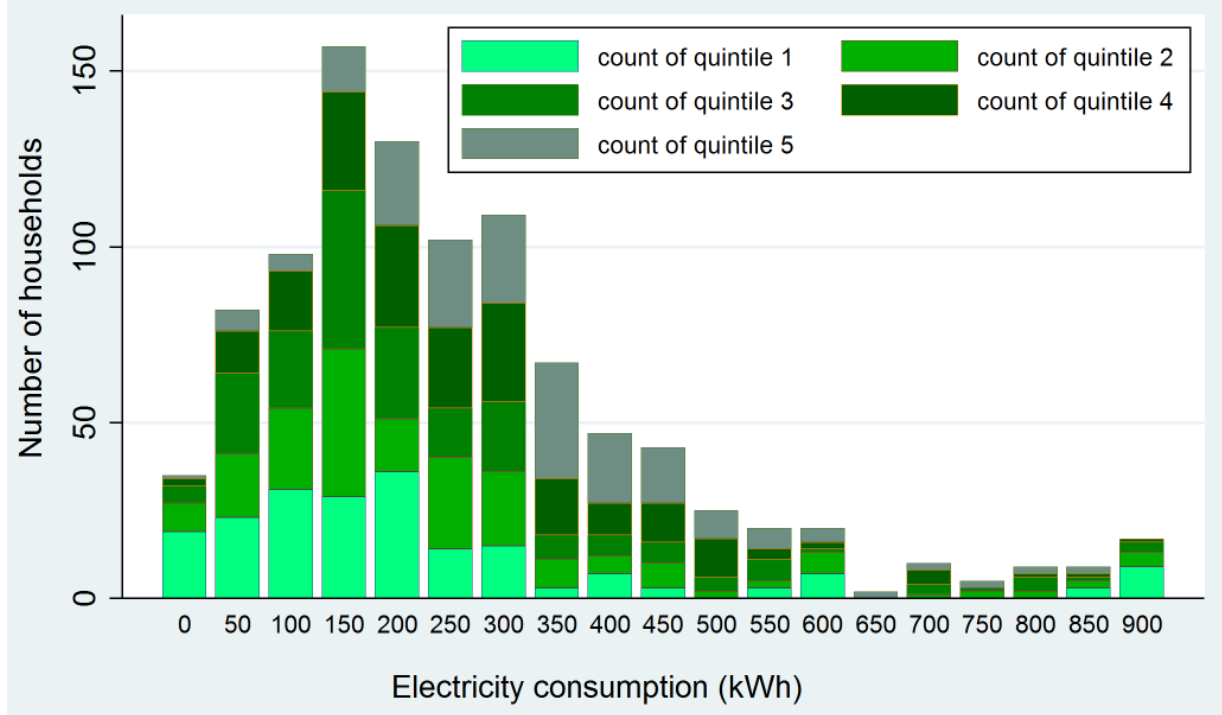

Figure 6. Distribution of Electricity Consumption among Sample and by Wealth Quintile, Addis Ababa, 2016 